\section{Processed Poultry Feather Fiber as an Alternative to Peat in Greenhouse Crops Substrates}

\author{
Michael R. Evans
}

AdDitIONAL INDEX WORDS. growing media, soil, peatmoss, potting mixes

Summary. Plant growth was evaluated in substrates containing varying proportions of processed poultry feather fiber (feather fiber). 'Cooler Blush' vinca (Catharanthus roseus) and 'Orbit Cardinal' geranium (Pelargonium $\times$ hortorum) dry shoot and dry root weights were not significantly different among plants grown in sphagnum-peat-based and perlitebased substrates containing $0 \%$ to $30 \%$ feather fiber. 'Pineapple Queen' coleus (Coleus blumei) dry shoot weights were not significantly different among plants grown in substrates containing $\mathbf{0 \%}$ to $\mathbf{5 0 \%}$ feather fiber. Coleus dry root weights were not significantly different among the substrates containing $0 \%$ to $40 \%$ feather fiber. 'Better Boy' tomato (Lycopersicon esculentum) dry shoot weights were not significantly different among the substrates containing $0 \%$ to $30 \%$ feather fiber. Tomato dry root weights were not significantly different among the substrates containing $0 \%$ to $30 \%$ feather fiber, but tomato grown in substrates containing $40 \%$ to $60 \%$ feather fiber had significantly lower dry root weights than tomato grown in substrates containing $0 \%$ to $30 \%$ feather fiber. 'Salad Bush' cucumber (Cucumis sativus) dry shoot and dry root weights were not significantly different between plants grown in $0 \%$ to $50 \%$ feather fiber, but those gown in substrates containing $60 \%$ feather fiber had significantly lower dry shoot weights than those grown in substrates containing $0 \%$ feather fiber. Dry shoot and root weights of coleus and tomato grown in SB-300 substrate amended with $20 \%$ or $30 \%$ feather fiber were not significantly different from coleus and tomato grown

$\overline{\text { Department of Horticulture, } 315 \text { Plant Sciences Build- }}$ ing, University of Arkansas, Fayetteville, AR 72701.

This project was supported by Tyson Foods, Springdale, Ark., and the Arkansas Agricultural Research and Extension Service. Published with approval of the Director, Arkansas Agricultural Experiment Station, manuscript no. in SB-300 without feather fiber. Dry shoot and dry root weights of coleus and tomato were significantly lower for plants grown in SB-300 amended with $40 \%$ feather fiber than for plants grown in SB-300 without feather fiber. For all species tested, plants grown in substrates containing up to $30 \%$ feather fiber were not significantly different from those grown in substrates containing $0 \%$ feather fiber and were of marketable qualities.

A rtificial substrates are commonly used in the production of containerized greenhouse and nursery crops (Nelson, 1998). Substrates are formulated from various organic and inorganic components to provide suitable physical and chemical properties as required by the specific crop and growing conditions (Bunt 1988). One of the most common materials used in the formulation of artificial substrates is sphagnum peat (peat). Environmental concerns (Barkham, 1993; Buckland, 1993; Robertson, 1993) and cost have generated significant interest in the development of alternatives to peat.

Most research on the development of alternatives to peat has been focused on agricultural, industrial and municipal waste products. Among these products were coconut coir (Evans and Stamps, 1996), cotton gin waste (Wang, 1991), waste paper products (Norrie and Gosselin, 1996; Chong and Cline, 1993), composted rice hulls (Laiche and Nash, 1990), kenaf(Wang, 1994), municipal sewage sludge (Mori et al., 1981), composted yard waste (Beeson, 1996) and various composted animal manures (Tyler et al., 1993). Some of these materials are not produced in large enough quantities to impact the market while others have proved too expensive for their intended use. Some of these materials have proven to be unsuitable because of their high degree of variability and their likelihood of containing contaminants such as metal fragments, glass, lead and mercury, while others have been used locally or regionally in niche markets.

Poultry feathers are a significant waste material produced by the meat processing industry. Depending on location and specific environmental regulatory requirements, feathers may be dried and ground for use in fertilizers (Choi and Nelson, 1996a; Choi and Nelson, 1996b; Hadas and Kautsky,
1994) and animal feeds (Brown and Pate, 1997; Palmquist et al., 1993), burned or landfilled. Being made almost entirely of the protein keratin, feathers are strong, biodegradable and contain about $15 \%$ nitrogen $(\mathrm{N})$ by weight (Hadas and Kautsky, 1994).

In cooperation with Tyson Foods (Springdale, Ark.), we developed a process to wash, press, disinfect and grind waste poultry feathers to produce a fibrous material that can be used as a component to reduce the amount of peat required to formulate substrates used to grow containerized greenhouse crops. The objective of this research was to evaluate plant growth of several common greenhouse crops in substrates in which varying percentages of the peat were replaced with feather fiber.

\section{Materials and methods}

Experiment 1. Growth of geraNIUM AND VINCA IN FEATHER FIBER-CONTAINING SUBSTRATES. Four substrates were formulated by blending processed poultry feather fiber (Tyson Foods, Springdale, Ark.), horticultural perlite [ 4 to $6 \mathrm{~mm}(0.16$ to 0.24 inch $)$ ] and peat (SunGro Horticulture, Bellevue, Wash.) at varying proportions. All substrates contained 20\% (by volume) perlite and $0 \%, 10 \%, 20 \%$, or $30 \%$ (by volume) processed feather fiber with the remainder being peat. For the substrate containing $0 \%$ feather fiber, calcitic lime was added to the peat to adjust the initial $\mathrm{pH}$ to 5.5 before mixing of the substrate. Because initial $\mathrm{pH}$ of feather fiber was 7.0 to 7.2 , no lime was added to the peat used in feather fiber-containing substrates. Initial $\mathrm{pH}$ of the substrates was $5.5,5.1,5.3$, and 5.7 for the $0 \%, 10 \%, 20 \%$, and $30 \%$ feather fiber substrates, respectively.

Four-leaf plugs [seedlings in size 288 plug trays with $5 \mathrm{~mL}\left(0.3\right.$ inch $\left.^{3}\right)$ volume per plug cell] of 'Orbit Cardinal' geranium and 'Cooler Blush' vinca were transplanted into $10.2-\mathrm{cm}$ (4-inch) plastic containers filled with each of the test substrates described.

Plants were placed into a glassglazed greenhouse. Greenhouse air temperatures were maintained between 20 and $25^{\circ} \mathrm{C}\left(68.0\right.$ and $\left.77.0^{\circ} \mathrm{F}\right)$. Plants were grown under ambient light levels (275 to $300 \mu \mathrm{mol} \cdot \mathrm{s}^{-1} \cdot \mathrm{m}^{-2}$ at $1200 \mathrm{HR}$ ). Immediately after being placed into the greenhouse, all substrates were drenched with $50 \mathrm{~mL}$ (1.7 fl oz) of $15 \%$ etridiazole and 25\% thiophanatemethyl (Banrot; Scotts, Marysville, 
Ohio) fungicide according to label directions. Plants were fertilized at each irrigation with a $200 \mathrm{mg} \cdot \mathrm{L}^{-1}(\mathrm{ppm})$ $\mathrm{N}$ solution using a $15 \mathrm{~N}-2.2 \mathrm{P}-12.5 \mathrm{~K}$ fertilizer (Excel 15-5-15 Cal Mag; Scotts, Marysville, Ohio).

After 8 weeks, the experiment was terminated. Dry shoot and root weights were determined. The experimental design was a complete randomized block with eight blocks and each species and substrate appearing once in each block. The experiment was repeated twice over time. No significant interaction occurred for time, so data from the experiment were pooled across time. An analysis of variance was conducted to determine if significant differences in plant growth occurred among the different substrates. Where significant differences occurred, a least significant difference mean separation test $(\alpha=0.05)$ was conducted to determine which means were significantly different from one another.

EXPERIMENT 2. GROWTH OF COLEUS, TOMATO AND CUCUMBER IN PEAT-BASED SUBSTRATES AMENDED WITH PROCESSED FEATHER FIBER. Except where indicated, protocols for Expt. 2 were as described for Expt. 1. Seven substrates were formulated by blending feather fiber, horticultural perlite and peat at varying proportions. All substrates contained $20 \%(\mathrm{v} / \mathrm{v})$ perlite and $0 \%, 10 \%, 20 \%$, $30 \%, 40 \%, 50 \%$, or $60 \%$ (v/v) feather fiber with the remainder being peat.

Two-leaf plugs [seedlings in size 288 plug trays with $5 \mathrm{~mL}$ volume per plug cell] of 'Better Boy' tomato and $5.1-\mathrm{cm}(2$-inch $)$ rooted cuttings of
'Pineapple Queen' coleus were transplanted into $10.2-\mathrm{cm}$ plastic containers filled with each of the test substrates described. Two seed of 'Salad Bush' cucumber seed were sown directly into containers filled with each substrate.

Greenhouse air temperatures were maintained between 20 and $28^{\circ} \mathrm{C}$ $\left(68.0\right.$ and $\left.82.4^{\circ} \mathrm{F}\right)$. Plants were grown under ambient light levels ( 270 to 335 $\mu \mathrm{mol} \cdot \mathrm{s}^{-1} \cdot \mathrm{m}^{-2}$ at $1200 \mathrm{HR}$ ). Immediately after being placed into the greenhouse, substrates planted with tomato and $\mathrm{co}^{-}$ leus were drenched with the fungicide Banrot (Scotts, Marysville, Ohio) at the recommended label rate. Cucumber were not drenched with fungicide.

After 4 weeks for tomato and cucumber and 6 weeks for coleus, the experiment was terminated. The experimental design was a complete randomized block with six blocks and each species and substrate occurring once per block. No significant interaction occurred for time, so data from the experiment were pooled across time.

EXPERIMENT 3. GROWTH OF COLEUS AND TOMATO IN SB-300 COMMERCIAL SUBSTRATE AMENDED WITH PROCESSEDPOULTRY FEATHERS. Except where indicated, protocols for Expt. 3 were as described for Expt. 2. Four substrates were formulated by blending feather fiber at $0 \%, 20 \%, 30 \%$, or $40 \%(\mathrm{v} / \mathrm{v})$ with the commercially available peat, composted bark and perlite-based growing media SB-300 (SunGro Horticulture, Bellevue, Wash.). Plugs of 'Better Boy' tomato and rooted cuttings of 'Pineapple Queen' coleus were transplanted into $10.2-\mathrm{cm}$ black plastic containers filled with each of the test substrates as described.

After 4 weeks for tomato and 6 weeks for coleus, the experiment was terminated. Dry shoot and root weights were determined. The experimental design was a complete randomized block with eight replications.

\section{Results and discussion}

Experiment 1. Growth of GeraNIUM AND VINCA IN FEATHER FIBER-CONTAINING SUBSTRATES. When grown in substrates containing $0 \%$ to $30 \%$ feather fiber geranium dry shoot and dry root weights ranged from $5.7 \mathrm{~g}$ to $6.1 \mathrm{~g}$ $(28.35 \mathrm{~g}=1.0 \mathrm{oz})$ and $0.8 \mathrm{~g}$ to $0.9 \mathrm{~g}$, respectively, and were not significantly different among the substrates (data not shown). Vinca dry shoot and dry root weights ranged from $1.1 \mathrm{~g}$ to 1.8 $\mathrm{g}$ and $0.2 \mathrm{~g}$ to $0.4 \mathrm{~g}$, respectively, and were not significantly different among the substrates (data not shown).

EXPERIMENT 2. GRowth OF COLEUS, TOMATO AND CUCUMBER IN PEAT-BASED SUBSTRATES AMENDED WITH PROCESSED FEATHER FIBER. Coleus dry shoot weights were not significantly different between plants grown in substrates containing $0 \%$ feather fiber and those grown in substrates containing 10\% to $50 \%$ feather fiber (Table 1). Coleus grown in substrates containing $60 \%$ feather fiber had significantly lower dry shoot weights than coleus grown in substrates containing $0 \%$ to $40 \%$ feather fiber. Coleus dry root weights were not significantly different among the substrates containing $0 \%$ to $40 \%$ feather fiber. However, coleus grown

Table 1. Growth of coleus, tomato and cucumber in sphagnum-peat-based substrates amended with processed poultry feather fiber (feather fiber).

\begin{tabular}{|c|c|c|c|c|c|c|c|c|}
\hline \multirow{2}{*}{\multicolumn{3}{|c|}{ Substrate component (\% by vol) }} & \multicolumn{2}{|c|}{ Coleus } & \multicolumn{2}{|c|}{ Tomato } & \multicolumn{2}{|c|}{ Cucumber } \\
\hline & & & \multirow{2}{*}{$\begin{array}{c}\text { Dry } \\
\text { shoot } \\
\text { wt }(g)^{z}\end{array}$} & \multirow{2}{*}{$\begin{array}{l}\text { Dry } \\
\text { root } \\
\text { wt }(g)\end{array}$} & \multirow{2}{*}{$\begin{array}{c}\text { Dry } \\
\text { shoot } \\
\text { wt (g) }\end{array}$} & \multirow{2}{*}{$\begin{array}{c}\text { Dry } \\
\text { root } \\
\text { wt }(g)\end{array}$} & \multirow{2}{*}{$\begin{array}{c}\text { Dry } \\
\text { shoot } \\
\text { wt (g) }\end{array}$} & \multirow{2}{*}{$\begin{array}{c}\text { Dry } \\
\text { root } \\
\text { wt }(g) \\
\end{array}$} \\
\hline $\begin{array}{l}\text { Sphagnum } \\
\text { peat }^{y}\end{array}$ & $\begin{array}{l}\text { Feather } \\
\text { fiber }\end{array}$ & Perlite & & & & & & \\
\hline 80 & 0 & 20 & 3.8 & 1.0 & 8.5 & 1.8 & 3.7 & 1.2 \\
\hline 70 & 10 & 20 & 4.2 & 0.9 & 8.8 & 2.1 & 4.3 & 1.3 \\
\hline 60 & 20 & 20 & 4.1 & 1.0 & 9.0 & 1.9 & 4.5 & 1.3 \\
\hline 30 & 50 & 20 & 2.7 & 0.5 & 6.2 & 0.9 & 2.8 & 0.9 \\
\hline 20 & 60 & 20 & 2.2 & 0.4 & 6.0 & 0.7 & 2.3 & 0.4 \\
\hline \multicolumn{9}{|l|}{ Significance } \\
\hline Substrate & & & * & * & ** & ** & * & * \\
\hline Block & & & NS & NS & NS & NS & NS & NS \\
\hline $\operatorname{LSD}(\alpha=$ & & & 1.2 & 0.4 & 0.7 & 0.4 & 0.9 & 0.5 \\
\hline
\end{tabular}

z28.35 g = $1.0 \mathrm{oz}$.

y Sphagnum peat used to formulate the $0 \%$ feather fiber substrate was amended with calcitic limestone to a pH of about 5.5 . Unamended sphagnum peat was used to formulate the remaining substrates.

NS,${ }^{*, *}$ Nonsignificant or significant at $P=0.05$ or 0.01 , respectively. 
Table 2. Growth of coleus and tomato in SB-300 substrate amended with processed poultry feather fiber (feather fiber).

\begin{tabular}{|c|c|c|c|c|c|}
\hline \multirow{2}{*}{\multicolumn{2}{|c|}{ Substrate components ( $\%$ by vol) }} & \multicolumn{2}{|c|}{ Coleus } & \multicolumn{2}{|c|}{ Tomato } \\
\hline & & \multirow{2}{*}{$\begin{array}{c}\text { Dry } \\
\text { shoot } \\
\text { wt }(\mathrm{g})^{\mathrm{z}}\end{array}$} & \multirow{2}{*}{$\begin{array}{c}\text { Dry } \\
\text { root } \\
\text { wt }(g)\end{array}$} & \multirow{2}{*}{$\begin{array}{c}\text { Dry } \\
\text { shoot } \\
\text { wt (g) }\end{array}$} & \multirow{2}{*}{$\begin{array}{c}\text { Dry } \\
\text { root } \\
\text { wt }(\mathrm{g})\end{array}$} \\
\hline SB-300 & Feather fiber & & & & \\
\hline 100 & 0 & 3.9 & 1.0 & 3.6 & 0.7 \\
\hline 80 & 20 & 4.2 & 1.1 & 2.8 & 0.6 \\
\hline 70 & 30 & 4.0 & 0.9 & 2.9 & 0.6 \\
\hline Substr & & * & * & * & * \\
\hline Block & & NS & NS & NS & NS \\
\hline $\operatorname{LSD}(\alpha$ & & 0.5 & 0.3 & 0.9 & 0.2 \\
\hline
\end{tabular}

in substrates containing $50 \%$ or $60 \%$ feather fiber had significantly lower dry root weights than coleus plants grown in substrates containing 0\% feather fiber.

Tomato dry shoot weights were not significantly different among the substrates containing $0 \%$ to $20 \%$ feather fiber (Table 1). Dry shoot weights were not significantly different between tomato plants grown in substrates amended with 0\% feather fiber and those grown in substrates amended with $10 \%$ to $30 \%$ feather fiber. Tomato plants grown in substrates containing $40 \%$ feather fiber had significantly lower root dry weights than those grown in the substrate without feather fiber. Tomato grown in substrates containing $50 \%$ or $60 \%$ feather fiber had significantly lower dry shoot weights than the tomato grown in substrates containing $0 \%$ to $40 \%$ feather fiber. Tomato dry root weights were not significantly different among the substrates containing $0 \%$ to $30 \%$ feather fiber. However, tomato grown in substrates containing $40 \%$ to $60 \%$ feather fiber had significantly lower dry root weights than tomato grown in substrates containing $0 \%$ to $30 \%$ feather fiber.

Cucumber dry shoot weights were not significantly different between the substrates containing $0 \%$ feather fiber and those containing $10 \%$ to $50 \%$ feather fiber (Table 1). Cucumber containing $60 \%$ feather fiber had significantly lower dry shoot weights than cucumber grown in substrates containing $0 \%$ to $40 \%$ feather fiber. Cucumber dry root weights were not significantly different between the substrates containing $0 \%$ feather fiber and those grown in substrates containing
$10 \%$ to $50 \%$ feather fiber. However, cucumber grown in substrates containing $60 \%$ feather fiber had significantly lower dry root weights than cucumber grown in substrates containing $0 \%$ to $30 \%$ feather fiber.

EXPERIMENT 3. Growth OF COLEUS AND TOMATO IN SB-300 COMMERCIAL SUBSTRATE AMENDED WITH FEATHER FIBER. Dry shoot and dry root weights of coleus and tomato grown in SB-300 substrate amended with $20 \%$ or $30 \%$ feather fiber were not significantly different from coleus grown in SB300 without feather fiber (Table 2). Dry shoot and dry root weights of coleus grown in SB-300 substrate amended with $40 \%$ feather fiber were significantly lower than those grown in SB-300 with $0 \%$ to $30 \%$ feather fiber. Dry shoot and root weights of tomato grown in SB-300 substrate with 40\% feather fiber added were significantly lower than those grown in SB-300 without feather fiber.

Geranium, vinca, coleus, tomato, and cucumber shoot and root growth of plants grown in substrates containing up to $30 \%$ feather fiber were similar to those grown in substrates containing $0 \%$ feather fiber. Although species responses differed, when the amount of feather fiber exceeded $30 \%$, shoot and root growth declined and, although not always significant, was lower than for those plants grown in $0 \%$ feather fiber. For all species tested, plants grown in substrates containing up to $30 \%$ feather fiber were of marketable qualities. Therefore, feather fiber was successfully used as a low-cost alternative to peat or as a spreading agent in combination with the SB-300 substrate to reduce the reliance on peat and to reduce the cost of the substrate.

\section{Conclusions}

Plants grown in peat-based and perlite-based substrates or the commercially obtained SB-300 substrate containing up to $30 \%$ feather fiber had similar dry shoot and dry root weights as those grown in substrates containing $0 \%$ feather fiber. Although species differed in their responses, when the amount of feather fiber exceeded $30 \%$, shoot and root growth declined and, although not always significant for all species tested, was lower than for those plants grown in $0 \%$ feather fiber. For all species tested, plants grown in substrates containing up to $30 \%$ feather fiber were of marketable qualities. Therefore, plants could be grown in substrates containing up to $30 \%$ feather fiber, thus reducing reliance on peat and reducing overall cost of the substrate.

\section{Literature cited}

Barkham, J.P. 1993. For peat's sake: Conservation or exploitation? Biodiversity Conserv. 2:556-566.

Beeson, R.C. 1996. Composted yard waste as a component of container substrates. J. Environ. Hort. 14:115-121.

Brown, W.F. and F.M. Pate. 1997. Cottonseed meal or feather meal supplementation of ammoniated tropical grass hay for yearly cattle. J. Animal Sci. 75:1666-1673.

Buckland, P. 1993. Peatland archeology: A conservation resource on the edge of extinction. Biodiversity Conserv. 2:513-517.

Bunt, A.C. 1988. Media and mixes for container grown plants. Unwin Hyman, Ltd., London.

Chong, C. and R.A. Cline. 1993. Response of four ornamental shrubs to container substrate amended with two sources of 
raw paper mill sludge. HortScience 28: 807-809.

Choi, J.M. and P.V. Nelson. 1996a. Developing a slow-release nitrogen fertilizer from organic sources. II. Using poultry feathers. J. Amer. Soc. Hort. Sci. 121:634-638.

Choi, J.M. and P.V. Nelson. 1996b. Developing a slow-release nitrogen fertilizer from organic sources. III. Isolation and action of a feather-degrading actinomycete. J. Amer. Soc. Hort. Sci. 121:639-643.

Evans, M.R. and R.H. Stamps. 1996. Growth of bedding plants in Sphagnum peat and coir dust-based substrates. J. Environ. Hort. 14:187-190.

Hadas, A. and L. Kautsky. 1994. Feather meal, a semi-slow-release nitrogen fertilizer for organic farming. Fert. Res. 38(2): 165-170.

Laiche, A.J. and V.E. Nash. 1990. Evaluation of composted rice hulls and lightweight clay aggregate as components of container-plant growth media. J. Environ. Hort. 8:14-18.

Mori, T., A. Narita, T. Amimoto, and M. Chino. 1981. Composting of municipal sewage sludge mixed with rice hulls. Soil Sci. Plant Nutr. 27(4):477-486.

Nelson, P.V. 1998. Greenhouse operation and management. 5th ed. Prentice Hall, Upper Saddle River, N.J.

Norrie, J. and A. Gosselin. 1996. Paper sludge amendments for turfgrass. HortScience 31:957-960.

Palmquist, D.M., M.R. Weisbjerg and T. Hvelplund. 1993. Ruminal, intestinal and total disgestibilities of nutrients in cows fed diets high in fat and undegradable protein. J. Dairy Sci. 76:1353-1364.

Robertson, R.A. 1993. Peat, horticulture and environment. Biodiversity Conserv. 2:541-547.

Tyler, H.H., S.L. Warren, T.E. Bilderback, and K.B. Perry. 1993. Composted turkey litter: II Effect on plant growth. J. Environ. Hort. 11:137-141.

Wang, Y.T. 1991. Evaluation of media consisting of a cotton waste for the production of tropical foliage species. J. Environ. Hort. 9:112-115.

Wang, Y.T. 1994. Using ground kenaf stem core as a major component of container media. J. Amer. Soc. Hort. Sci. 119: 931-935. 